\title{
Psychosocial risks for diabetic control of preadolescents and adolescents with Diabetes Mellitus Type I
}

\author{
Miodrag Stankovic ${ }^{\text {* }}$, Sandra Stankovic², Grozdanko Grbesa', Sasa Zivic², Ljubisa Milosavljevic ${ }^{1}$ \\ From $1^{\text {st }}$ International Congress on Neurobiology and Clinical Psychopharmacology and European \\ Psychiatric Association Conference on Treatment Guidance \\ Thessaloniki, Greece. 19-22 November 2009
}

\section{Background}

The aim of the research is to mark psychosocial risks for diabetic preadolescents and adolescents and healthy control between 11 and 18 years old.

\section{Materials and methods}

Examinees completed questionnaires included FACES III, EPQ, Beck Depression Inventory (BDI), SCOFF and Overall Sociodemografic Inventory. Physicians completed patients' medical history and C-GAS scale of diabetic children. Subjects were asked to identify how they perceived themselves, their affective state, eating, sleeping, sexual behavior, family cohesion and adaptability. Physicians were asked to identify level of psychological, social, and school functioning of preadolescents and adolescents. Diabetic control was determinated by measuring glycosylated hemoglobin (GHgBA1c).

\section{Results}

Results revealed that patients almost uniformly had very low scores on BDI $(\mathrm{p}<0.001)$, low social skills, and both, patients and parents were in chaotically enmeshed family systems and tend to reach more chaotically enmeshed scores on ideal parent-child relationship ( $\mathrm{p}<$ 0.0005). Statistically, more patients, had tendency of not using professional and peer group support. Differences are more enhanced with worst diabetic control. Extraverted adolescents had worse diabetic control, and higher scores for eating disorders $(\mathrm{p}<0.001)$.

\section{Conclusions}

Perceiving family system as only supportive surrounding, denegation of psychological disturbances, with tendency of not using professional and peer group support and extravert personal traits are significant psychosocial risks for worst diabetic control within preadolescents and adolescents populations.

\section{Author details}

${ }^{1}$ Clinic for Mental Health Protection, University Clinical Centre, Nis, Serbia. ${ }^{2}$ Pediatric Clinic, University Clinical Centre, Nis, Serbia.

Published: 22 April 2010

doi:10.1186/1744-859X-9-S1-S219

Cite this article as: Stankovic et al:: Psychosocial risks for diabetic

control of preadolescents and adolescents with Diabetes Mellitus Type I. Annals of General Psychiatry 2010 9(Suppl 1):S219.

\footnotetext{
${ }^{1}$ Clinic for Mental Health Protection, University Clinical Centre, Nis, Serbia
}

Submit your next manuscript to BioMed Central and take full advantage of:

- Convenient online submission

- Thorough peer review

- No space constraints or color figure charges

- Immediate publication on acceptance

- Inclusion in PubMed, CAS, Scopus and Google Scholar

- Research which is freely available for redistribution 